\title{
The Effects of Physical Activity Programs on Physical Fitness, Blood Lipids, and Growth-Related Factors among Young Normal Weight and Obese Children
}

\author{
Hyong-Gon Bak', Gun-Do Kim² and Chan-Ho Park ${ }^{1} *$ \\ ${ }^{1}$ Department of Physical Education, Pusan National University, Busan 609-735, Korea \\ ${ }^{2}$ Department of Microbiology, Pukyong National University, Busan 608-737, Korea
}

Received December 13, 2011 /Revised January 25, 2012 / Accepted January 26, 2012

\begin{abstract}
This study was conducted to examine the effects of physical activity programs on young children's body composition, physical fitness, blood lipids, and growth-related factors. Fourteen young male child subjects participated in this study. Experimental groups were divided into a young obese children group (OG; $n=7$ ) and a young normal weight children group (NG; $n=7$ ). The subjects performed supervised physical activity programs with moderate intensity for 12 weeks, 40 minutes per session, 3 times per week. The results of this study are as follows: HDL-C, growth hormone, and IGF-I were significantly increased in NG, but OG was showed no changes. Physical fitness was significantly increased in both NG and OG. This study demonstrated that physical activity programs have a positive effect on the prevention of obesity, as well as a positive effect on growth and development in young normal weight children. However, long-term follow-up studies are necessary to clarify the additive effect of exercise program with behavior modification in young obese children.
\end{abstract}

Key words : Physical activity program, obesity, fitness, young children

\section{서 론}

유아는 출생초기에 반사적이거나 미분화된 움직임으로 초 보적 활동에 참여하고 약 2세가 되면 걷고, 달리고, 뛰는 기본 적인 운동능력이 발달하며, 약 7세가 될 때가지 운동기능이 점진적으로 발달한다[17]. 유아기의 신체적 반응과 판단능력 은 운동을 경험함으로써 효과적으로 발달 될 수 있다. 세계보 건기구 $(\mathrm{WHO})$ 와 미국스포츠의학회(ACSM)는 유아기와 청소 년기의 신체활동의 장점과 중요성을 제시하고 있으며, 신체활 동은 성장과정의 아이들에게 신체적인 발달뿐 아니라 인지기 능(cognitive function) 발달에도 영향을 미치고 있음을 지적하 고 있다[26].

아동과 청소년비만 증가는 선진국과 개발도상국을 가릴 것 없이 전 세계적인 문제로 부각되고 있으며, 이 같은 비만 유병 률 증가 원인은 운동부족, 영양과잉, 신체활동부족 등을 들 수 있다. 유아들도 운동부족이라는 심각한 문제에 노출되면 허약아, 비만아, 정신불안상태 그리고 조기시력 감퇴현상 등 의 새로운 문화병에 직면하게 된다[21]. 유아비만에 있어서 중 요한 문제점은 대부분 성인비만으로 발전된다는 것이다. 연령 별로 보면 생후 6개월 영유아의 비만은 약 $14 \%$, 만 4 7세 유아 의 비만은 $41 \%$, 그리고 13 세의 학동기 아동의 비만은 약 $70 \%$ 수준에서 성인 비만으로 이행된다[26]. 비만은 2세 이후부터 적극적인 체중 조절이 필요하고 2 7세 사이에 비만이면 아동

*Corresponding author Tel : +82-51-500-7990, Fax : +82-51-506-7991

E-mail : chanholab@hanmail.net
비만이 될 확률은 $50 \%$ 이며, 생활습관이 개선되지 않으면 $80 \%$ 가 성인비만으로 이어진다고 한다[6]. 발육단계에 발생되는 비 만이 특별한 관심을 갖는 것은 지방대사이상과 내분비 기능이 상을 동반하게 되어 충분한 성장이 이루어지지 않는다는 것이 다[3]. 이러한 현상은 비만이 성장작용에 관여하는 성장호르몬 (Growth Hormone, $\mathrm{GH}$ )에 가장 큰 영향을 미치기 때문이다. 이와 관련하여 성장관련 호르몬의 분비에 운동이 미치는 영향 에 관한 연구들은 다각적으로 수행되어 왔으며[14], 아동 시기 에 $\mathrm{GH}$ 는 규칙적인 운동에 의해 분비량이 증가된다고 보고되 었다[18]. 또한 인슐린유사 성장인자-I(Insulin like Growth Factor-I, IGF- I)은 운동 실시 후 증가하는 경향을 보이며, GH 의 증가와 비례하여 매우 높은 상관관계가 있는 것으로 나타 났다[4]. GH는 인체에서 뼈와 연골조직, 골격근 및 다른 조직 의 성장과정에 밀접하게 관련되어 있다[10]. 특히 $\mathrm{GH}$ 는 장시 간 운동을 실시할 경우 분비가 증가되어 IGF- I의 합성을 촉진 하게 되며, 운동에 따른 근 수축이 활발하게 이루어져서 골격 근의 성장 및 비대를 유발하는 것으로 보고되고 있다[9]. 그러 나 유아들이 신체활동의 기회를 충분히 가지지 못한다면 이러 한 효과를 기대하기는 어렵게 된다. 반면 과잉 영양공급, 운동 량 부족으로 비만 유아가 많아져 유아기의 체력발달과 성장발 달에 부정적인 영향을 미칠 수도 있다.

최근에는 신체활동 부족이 비만, 성장 및 체력저하, 그리고 생활습관병의 원인으로 인식되어 유아교육에 있어서 신체활 동이 중요시 되고 있다. 이러한 시점에서 유아들의 신체적 발 달과 비만 예방에 도움이 될 수 있는 프로그램 개발이 필요하 다. 하지만 유아체육프로그램이 비만유아와 정상체중유아에 
어떠한 영향을 미치는지에 관한 비교분석연구가 미흡한 실정 이다. 따라서 본 연구에서 실시한 유아체육프로그램이 비만유 아와 정상체중유아에게 어떠한 영향을 미치는지 비교 분석하 고자 본 연구를 수행하게 되었다.

\section{재료 및 방법}

\section{연구대상}

본 연구의 대상은 $\mathrm{B}$ 광역시에 소재한 $\mathrm{D}$ 대학 부속유치원 6세 학급 두 반 60 명 유아를 대상으로 신장, 체중은 각각 대한소아 과학회의 한국 소아의 연령별 기준치와 비교하여 백분위를 산출하였고, 백분위 값을 참고로 하여 15 백분위 이상 85 백분 위 미만의 정상범위에 속하는 경우에는 정상체중군으로 85 백 분위 이상은 비만군으로 분류하였고, 원아 중 본 연구의 프로 그램에 참가하기를 원하고 특별한 운동경험이 없고 식사요법 에 참여하지 않은 유치원생의 학부모에게 본 연구의 취지와 운동프로그램을 안내한 후 참여 동의서를 제출한 남자 비만유 아 7명과 정상체중유아 7명 을 연구 대상자로 선정 하였으며, 신체적 특성은 Table 1 과 같다.

\section{측정방법 및 분석방법}

본 연구의 혈액 채취는 $\mathrm{S}$ 임상실험센터에서 혈중지질 및 성장 관련인자검사를 실시하였다. 측정항목은 신체조성, 체력 (근지구력, 유연성, 순발력, 평형성, 협응성), 혈중지질(T-C, $\mathrm{TG}, \mathrm{HDL}-\mathrm{C}, \mathrm{LDL}-\mathrm{C})$ 및 성장 관련인자(GH, IGF- I)이며, 모든 검사항목은 사전, 사후 동일한 방법과 조건으로 검사 전날 공 복상태를 유지하게 한 후 다음날 오전 09 10시 사이에 실시하 였다. 혈액은 전완주정맥(cubital vein)에서 $10 \mathrm{ml}$ 를 채혈하였 으며, 채혈된 혈액은 냉동보관 되어 $\mathrm{S}$ 임상실험센터에 분석을 의뢰하였다.

신체조성의 측정은 DSM (direct segmental measurement) 방식인 체조성 분석기(InBody J10)로 신장, 체중, 체지방량, 제 지방량, 체지방률을 측정 하였으며, TC, TG, HDL-C, LDL-C 분석은 전완 정맥에서 채취한 혈액을 원심분리기 Brushless D. C Motor VS-5500 (Brushless. Co)를 이용하여 10분간 1,500 2,000 rpm의 속도로 원심 분리한 다음, 혈장만 검사 튜 브에 분리하여 건식 생화학 분석기 Toshiba 120-FR (Toshiba. $\mathrm{Co}$ )를 이용하여 분석 하였다. GH는 IGF- I 은 1470 wizard $\gamma$-Counter (Japan)를 사용하여 IRMA (Immunoradionmetric assay)방법으로 분석하였다.

체력 측정방법은 유아 기초체력 테스트 방법[22]을 참고로 하여 근지구력, 유연성, 순발력, 평형성, 협응성을 측정하였다. 각 체력 요소별 측정 방법은 다음과 같다.

근지구력 측정은 유아가 서서 발을 자연스럽게 내린 자세 에서 팔꿈치 높이 정도의 책상 2 개를 어깨 넓이로 양쪽에 배 치한 후 유아를 책상사이에 서게 한다. 준비 신호로 양팔을 굽히고 책상 위에 손을 얹어 놓고 시작 신호에 따라 양팔을 펴면서 바닥에서 떼어 놓고 양팔로 체중을 지탱하면서, 팔을 굽힐 때까지 계속한다. 팔이 굽거나, 손바닥 이외의 신체 부 분이 책상에 닿을 때에는 실패로 간주한다. 발이 바닥에서 떨어질 때부터 실패할 때까지의 지속시간을 초(sec) 단위로 기록한다.

유연성 측정은 유아를 매트위에 발을 뻗고 앉게 하여 발꿈 치를 $20 \mathrm{~cm}$ 간격으로 벌리고 양 손을 펴서 발 사이에 놓는다. 상체를 앞으로 굽히면서 양손을 매트위에 스치며, 될 수 있는 한 앞으로 뺃는다. 손가락 끝이 닿은 가장 먼 곳에 백묵으로 표시한 다음 양 팔꿈치를 연결한 일직선에서 부터의 거리를 측정하며 무릎이 굽지 않도록 한다. 이를 방지하기 위하여 보 조자가 뒤에서 무릎을 양손으로 눌러 주어도 되며, 기록을 $\mathrm{cm}$ 단위로 측정하였다.

순발력 측정은 도약선을 밟지 않고 양발을 동시에 굴러서 멀리 뛴다. 두 손을 흔들어서 반동을 이용하며 뛸 때 하나, 둘, 셋의 구령에 맞추어 뛰게 할 수 있다. 도약선과 착지한 지점(도약선에 가까운 발꿈치의 위치 $)$ 의 최단거리 $(\mathrm{cm})$ 를 측정 한다. 2회 실시하여 좋은 기록을 택한다.

평형성 측정은 평균대에 서로 발을 뺃어 평균대 위에 올린 다음 다른 발을 가볍게 지면에서 뗀다. 평균대 위에서 될 수 있는 한 오래 평형을 유지하도록 하고 서있는 발의 발바닥 전면이 봉에 닿도록 하고, 한발이 바닥이나 봉에 닿았을 때, 서 있는 발이 봉에 닿았을 때, 신체의 어느 부분이든지 바닥이 나 봉에 닿았을 때 같은 경우 무효임을 시범을 통하여 알린다. 좌우 2 회씩 바꾸어 실시하며, 실패하기까지의 시간을 10 분의 1 초 $(\mathrm{sec})$ 단위로 측정한다. 좌우 어느 쪽이든지 좋은 기록을 택한다.

협응성 측정은 $4 \mathrm{~m} 50 \mathrm{~cm}$ 의 거리에 $50 \mathrm{~cm}$ 마다 표시를 하여 그 표시 위에 각종의 중심이 되도록 10 개를 나열한다. 유아를 최초의 유니바 뒤에 서게 한 다음 출발의 신호에 따 라 하나하나의 유니바 위를 뛰어넘어서 앞으로 전진 하도록

Table 1. Characteristics of the subjects

\begin{tabular}{ccccc}
\hline Gruop & Age $(\mathrm{yrs})$ & Height $(\mathrm{cm})$ & Weight $(\mathrm{kg})$ & $\%$ fat $(\%)$ \\
\hline OG $(\mathrm{n}=7)$ & $6.02 \pm .33$ & $120.00 \pm 3.17$ & $26.88 \pm 1.96$ & $27.27 \pm 6.15$ \\
NG $(\mathrm{n}=7)$ & $6.09 \pm .35$ & $116.97 \pm 2.92$ & $20.35 \pm 1.94$ & $14.60 \pm 2.82$ \\
\hline
\end{tabular}

Values are mean \pm standard deviation OG: obesity group, NG: normal group 
하고, 양쪽 발에 시간차가 있거나 각목을 2개 이상 한 번에 뛰어 넘는 경우, 각목 위에 올라가든지, 발길로 차게 되면 무효이다. 도중에 휴식하며, 그때까지의 기록만을 기록하고, 2 회 실시하여 좋은 기록을 택한다. 실패 없이 10 개의 유니바 를 뛰어넘을 때까지의 시간을 10 분의 1 초 $(\mathrm{sec})$ 단위로 기록 한다.

\section{운동방법}

유아체육프로그램은 선행연구에서 제시한 프로그램[22]을 참고로 본 연구자가 유아교육기관에서 예비검사(pilot test)프 로그램 실시 후 본 연구자가 프로그램 수정 보안 후 구성하였 다. 비만유아와 정상체중유아를 매주 3회씩(월, 수, 금) 12 주 동안 총 36회를 구성 하였으며, 유아교육 과정에 최대한 적합 한 시간을 고려하여 원아들의 일과 중 오후 12 시 20 분부터 40 분 동안 실시하였으며, 구성순서는 준비운동, 본 운동, 정리 운동의 순서로 진행되었다. 운동프로그램을 실시하기 1 주 전 운동프로그램에 대한 이해와 운동기술에 대한 정보를 습득 할 수 있도록 1 주간의 적응기간을 두었다. 본 연구의 유아체육 프로그램은 Table 2와 같다.

\section{자료처리}

본 연구에서는 SPSS Ver 12.0 package를 이용하여 모든 변 인에 대한 평균(M)과 표준편차(SD)를 산출하였고, 프로그램 실시 전·후의 항목별 평균치 변화에 대한 차이 검증은 대응 표본 $t$-검정(paired $t$-test)을 이용하였으며, 통계적 유의수준은 $a=0.05$ 로 하였다.

\section{결 과}

\section{신체조성 및 혈중지질의 변화}

Table 3에서 보는 바와 같이 제지방량(FFM)은 비만군에 서 12 주간 운동전 $19.45 \pm 0.77 \mathrm{~kg}$ 에서 운동 후 $19.41 \pm 1.09 \mathrm{~kg}$ 로 감소하였으나 유의한 차이는 없었고, 정상군에서 $17.36 \pm 1.39 \mathrm{~kg}$ 에서 $17.84 \pm 1.60 \mathrm{~kg}$ 로 증가하였으며 유의한 차 이 $(p<0.05)$ 가 있었다. 체지방률은 비만군은 사전 $27.27 \pm 6.15 \%$ 에서 사후 $30.15 \pm 5.33 \%$ 로 유의하게 $(p<0.05)$ 증가하였으며, 정상군은 $14.60 \pm 2.82 \%$ 에서 $17.05 \pm 2.74 \%$ 로 유의하게 $(p<0.01)$ 증가하였다. Table 5에서 보는 바와 같이 $\mathrm{TC}$ 는 비만군에서 $160.00 \pm 12.87 \mathrm{mg} / \mathrm{dl}$ 에서 $161.85 \pm 12.66 \mathrm{mg} / \mathrm{dl}$ 로, 정상군은 $177.71 \pm 28.69 \mathrm{mg} / \mathrm{dl}$ 에서 $182.42 \pm 21.30 \mathrm{mg} / \mathrm{dl}$ 로 증가하였으 나 유의한 차이가 없었다. TG는 비만군에서 $62.28 \pm 26.78$ $\mathrm{mg} / \mathrm{dl}$ 에서 $49.42 \pm 21.59 \mathrm{mg} / \mathrm{dl}$ 로, 정상군에서 $65.00 \pm 36.04$ $\mathrm{mg} / \mathrm{dl}$ 에서 $44.42 \pm 10.64 \mathrm{mg} / \mathrm{dl}$ 로 감소하였으나 유의한 차 이가 없었다. HDL-C는 비만군에서 $64.61 \pm 10.09 \mathrm{mg} / \mathrm{dl}$ 에서 $63.45 \pm 5.84 \mathrm{mg} / \mathrm{dl}$ 로 증가하였으나 유의한 차이가 없었고, 정상군는 $63.48 \pm 13.01 \mathrm{mg} / \mathrm{dl}$ 에서 $68.77 \pm 10.47 \mathrm{mg} / \mathrm{dl}$ 로 유 의하게 $(p<0.05)$ 증가하였다. LDL-C는 비만군에서 $89.85 \pm 11.92$ 에서 $\quad 88.85 \pm 19.54$ 로, 정상군은 $\quad 106.85 \pm 18.26$ $\mathrm{mg} / \mathrm{dl}$ 에서 $105.28 \pm 14.96 \mathrm{mg} / \mathrm{dl}$ 로 약간 감소하였으나 유의 한 차이는 없었다.

Table 2. Child physical activity program

\begin{tabular}{|c|c|c|c|c|}
\hline Order & Period & Contents & Intensity & Frequency \\
\hline Warm-up (5 min) & $1 \sim 12$ wks & Rhythmic Movement, Streching & & \multirow{8}{*}{$\begin{array}{c}3 \text { times } \\
\text { / wks }\end{array}$} \\
\hline \multirow{6}{*}{$\begin{array}{c}\text { Main } \\
\text { exercise } \\
(30 \mathrm{~min})\end{array}$} & $1 \sim 2$ wks & Univa, Mat Exercise & \multirow{3}{*}{$\begin{array}{c}\text { 11 12 } \\
\text { RPE }\end{array}$} & \\
\hline & $3 \sim 4$ wks & Beat board, Mat Exercise & & \\
\hline & $5 \sim 6 \mathrm{wks}$ & Beat board, Mat, Vaulting horse Exercise & & \\
\hline & $7 \sim 8 \mathrm{wks}$ & Rope, Ball Exercise & \multirow{3}{*}{$\begin{array}{c}13 \sim 15 \\
\text { RPE }\end{array}$} & \\
\hline & 9 10 wks & Balance beam, Mat Exercise & & \\
\hline & $11 \sim 12$ wks & Multi Apparatus Exercise & & \\
\hline Cool-down (5 min) & $1 \sim 12$ wks & Rhythmic Movement, Streching & & \\
\hline
\end{tabular}

Table 3. Changes of body compositon

\begin{tabular}{lcccccc}
\hline \multirow{2}{*}{ Variable } & \multicolumn{3}{c}{ OG $(\mathrm{n}=7)$} & \multicolumn{3}{c}{ NG $(\mathrm{n}=7)$} \\
\cline { 2 - 7 } & Pre & Post & $t$-value & Pre & Post & $t$-value \\
\hline Hight & $120.0 \pm 3.1$ & $121.0 \pm 3.5^{*}$ & -5.63 & $116.9 \pm 2.9$ & $118.2 \pm 3.0^{*}$ & -6.51 \\
Weight & $26.88 \pm 1.96$ & $27.91 \pm 2.23^{* *}$ & -5.45 & $20.35 \pm 1.94$ & $21.51 \pm 2.25^{* * *}$ & -5.45 \\
FFM & $19.45 \pm 0.77$ & $19.41 \pm 1.09$ & .244 & $17.36 \pm 1.39$ & $17.84 \pm 1.60^{*}$ & -2.90 \\
\% Fat & $27.27 \pm 6.15$ & $30.15 \pm 5.33^{*}$ & -3.60 & $14.60 \pm 2.82$ & $17.05 \pm 2.74^{* *}$ & -3.87 \\
\hline
\end{tabular}

Values are mean \pm standard deviation

FFM: Free Fat Mass

*: Significant difference within group in paired $t$-test, $" p<0.05,{ }^{* *} p<0.01,{ }^{* * *} p<0.001$ 
Table 4. Changes of physical fitness

\begin{tabular}{lcccccc}
\hline \multirow{2}{*}{ Variable } & \multicolumn{3}{c}{ OG $(\mathrm{n}=7)$} & \multicolumn{2}{c}{ NG $(\mathrm{n}=7)$} \\
\cline { 2 - 7 } & Pre & Post & $t$-value & Pre & Post & $t$-value \\
\hline Muscular endurance & $13.27 \pm 8.02$ & $15.04 \pm 8.81^{*}$ & -2.98 & $24.65 \pm 15.15$ & $31.46 \pm 15.37^{*}$ & -3.13 \\
Flexibility & $7.57 \pm 3.15$ & $9.35 \pm 3.14$ & -2.36 & $4.85 \pm 9.29$ & $11.64 \pm 5.57^{*}$ & -2.74 \\
Explosive strength & $88.14 \pm 20.07$ & $99.28 \pm 14.28^{*}$ & -2.79 & $106.62 \pm 11.88$ & $114.28 \pm 11.18$ & -2.00 \\
Balance & $9.87 \pm 9.10$ & $16.77 \pm 7.86^{*}$ & -3.08 & $27.43 \pm 15.67$ & $37.92 \pm 23.43^{*}$ & -2.98 \\
Coordination & $14.03 \pm 10.36$ & $6.30 \pm 2.66^{*}$ & 2.54 & $7.23 \pm 1.44$ & $4.41 \pm 0.77^{* * *}$ & 7.08 \\
\hline
\end{tabular}

Values are mean \pm standard deviation

$\stackrel{*}{*}$ Significant difference within group in paired $t$-test, ${ }^{*} p<0.05,{ }^{* *} p<0.01,{ }^{* * *} p<0.001$

Table 5. Changes of blood lipid and growth-related factors

\begin{tabular}{lcccccc}
\hline \multirow{2}{*}{ Variable } & \multicolumn{3}{c}{ OG $(\mathrm{n}=7)$} & \multicolumn{3}{c}{ NG $(\mathrm{n}=7)$} \\
\cline { 2 - 6 } & Pre & Post & $t$-value & Pre & Post & $t$-value \\
\hline TC $(\mathrm{mg} / \mathrm{dl})$ & $160.00 \pm 12.87$ & $161.85 \pm 12.66$ & -0.40 & $177.71 \pm 28.69$ & $182.42 \pm 21.30$ & -1.13 \\
TG $(\mathrm{mg} / \mathrm{dl})$ & $62.28 \pm 26.78$ & $49.42 \pm 21.59$ & 1.13 & $65.00 \pm 36.04$ & $44.42 \pm 10.64$ & 1.53 \\
HDL-C $(\mathrm{mg} / \mathrm{dl})$ & $64.61 \pm 10.09$ & $63.45 \pm 5.84$ & 1.13 & $63.48 \pm 13.01$ & $68.77 \pm 10.47^{*}$ & 1.53 \\
LDL-C $(\mathrm{mg} / \mathrm{dl})$ & $89.85 \pm 11.92$ & $88.85 \pm 19.54^{*}$ & 0.21 & $106.85 \pm 18.26$ & $105.28 \pm 14.96$ & 0.61 \\
GH $(\mathrm{ng} / \mathrm{ml})$ & $2.84 \pm 4.34$ & $4.72 \pm 4.79$ & -2.14 & $1.58 \pm 0.74$ & $2.45 \pm 0.70^{*}$ & -2.55 \\
IGF-1 $(\mathrm{ng} / \mathrm{ml})$ & $245.25 \pm 55.35$ & $276.17 \pm 75.12$ & -1.92 & $170.00 \pm 40.93$ & $226.75 \pm 64.73^{*}$ & -3.62 \\
\hline Values are $m e a n+s a n$
\end{tabular}

Values are mean \pm standard deviation

*: Significant difference within group in paired $t$-test, ${ }^{*} p<0.05,{ }^{* *} p<0.01,{ }^{* * *} p<0.001$

\section{체력의 변화}

Table 4 에서 보는 바와 같이 근지구력은 비만군에서 $13.27 \pm$ $8.02 \mathrm{sec}$ 에서 $15.04 \pm 8.81 \mathrm{sec}$ 로 유의하게 $(p<0.05)$ 증가하였으 며, 정상군은 $24.65 \pm 15.15 \mathrm{sec}$ 에서 $31.46 \pm 15.37 \mathrm{sec}$ 로 유의하게 $(p<0.05)$ 증가하였다. 유연성은 비만군에서 $7.57 \pm 3.15 \mathrm{~cm}$ 에서 $9.35 \pm 3.14 \mathrm{~cm}$ 로 증가하였으나 유의한 차이가 없었고, 정상군 은 $4.85 \pm 9.29 \mathrm{~cm}$ 에서 $11.64 \pm 5.57 \mathrm{~cm}$ 로 유의하게 $(p<0.05)$ 증가 하였으며 유의한 차이 $(p<0.05)$ 가 있었다. 순발력은 비만군에 서 $88.14 \pm 20.07 \mathrm{~cm}$ 에서 $99.28 \pm 14.28 \mathrm{~cm}$ 로 유의하게 $(p<0.05)$ 증 가하였으나, 정상군은 $106.62 \pm 11.88 \mathrm{~cm}$ 에서 $114.28 \pm 11.18 \mathrm{~cm}$ 로 증가하였으나 유의한 차이는 나타나지 않았다. 평형성은 비만군에서 $9.87 \pm 9.10 \mathrm{sec}$ 에서 $16.77 \pm 7.86 \mathrm{sec}$ 로 정상군은 $27.43 \pm 15.67 \mathrm{sec}$ 에서 $37.92 \pm 23.43 \mathrm{sec}$ 로 두 집단 모두 유의하게 $(p<0.05)$ 증가하였다. 협응성은 비만군에서 $14.03 \pm 10.36 \mathrm{sec}$ 에 서 $6.30 \pm 2.66 \mathrm{sec}$ 로 유의하게 $(p<0.05)$ 감소하였으며, 정상군은 $7.23 \pm 1.44 \mathrm{sec}$ 에서 $4.41 \pm 0.77 \mathrm{sec}$ 로 유의하게 $(p<0.001)$ 감소하 는 것으로 나타났다.

\section{성장관련인자의 변화}

Table 5에서 보는 바와 같이 $\mathrm{GH}$ 는 비만군에서 $2.84 \pm 4.34$ $\mathrm{ng} / \mathrm{ml}$ 에서 $4.72 \pm 4.79 \mathrm{ng} / \mathrm{ml}$ 로 증가하였으나 유의한 차이는 없었고, 정상군은 $1.58 \pm 0.74 \mathrm{ng} / \mathrm{ml}$ 에서 $2.45 \pm 0.70 \mathrm{ng} / \mathrm{ml}$ 로 유 의하게 $(p<0.05)$ 증가하였다. IGF-I는 비만군에서 $245.25 \pm 55.35$ $\mathrm{ng} / \mathrm{ml}$ 에서 $276.17 \pm 75.12 \mathrm{ng} / \mathrm{ml}$ 로 증가하였으나 유의한 차이 는 없었고, 정상군은 $170.00 \pm 40.93 \mathrm{ng} / \mathrm{ml}$ 에서 $226.75 \pm 64.73$ $\mathrm{ng} / \mathrm{ml}$ 로 유의하게 $(p<0.05)$ 증가하였다.

\section{고 찰}

\section{신체조성 및 혈중지질의 변화}

신체조성은 운동수행능력과 깊은 관련이 있으며, 본 연구에 서 유아체육프로그램에 따른 체지방률의 변화는 비만군 $(p<0.05)$ 과 정상군 $(p<0.01)$ 에서 모두 유의하게 증가하는 것으 로 나타났다. 본 연구에서 실시한 유아체육프로그램이 유아들 의 체지방량을 감소시키는 효과는 나타나지 않았다. 하지만 정상군에서 제지방량이 유의하게 $(p<0.05)$ 증가하였다. 특히 성장과정에 있는 아동들의 제지방량의 증가는 여아는 6세, 남 아는 9.5세에 시작된다[24]. 본 연구에 참가한 정상체중유아들 은 모두 남아들로 평균 연령 6세에 해당하며, 제지방량이 증가 하는 시기가 아니더라도 규칙적인 신체활동을 하면 제지방량 이 증가하는 긍정적인 효과를 얻을 수 있을 것으로 사료된다.

혈중 콜레스테롤 농도가 증가함에 따라 허혈성 심장질환의 발생률이 지속적으로 상승하며, 관상동맥질환, 고혈압, 뇌졸 중, 고지혈증 등의 생활습관병을 유발시키는 위험인자이다. 비만아동은 정상아동에 비하여 T-C, LDL-C, TG는 높고 $\mathrm{HDL}-\mathrm{C}$ 는 낮으며 비만도가 증가할수록 유의한 상관관계가 있 다[24]. 또한 정기적인 운동 및 신체활동은 T-C와 LDL-C의 감소와 $\mathrm{HDL}-\mathrm{C}$ 의 증가 및 $\mathrm{TG}$ 의 심혈관질환에 미치는 위험인 자를 억제 및 개선시킨다[1]. 하지만 본 연구에서 유아체육프 로그램에 따른 비만유아와 정상체중유아의 혈중지질의 변화 는 정상군에서 $\mathrm{HDL}-\mathrm{C}$ 만 유의하게 증가 $(p<0.05)$ 한 것으로 나 타났으며, 나머지 변인은 유의한 차이가 없었다. 이러한 결과 는 T-C가 운동만으로는 잘 감소하지 않고 운동기간에도 영향 
을 받지 않으며[7], 식이요법과 운동요법을 병행하여 실시할 경우에는 감소하는 것으로 보고되고 있다[13]. 본 연구에서 T-C의 증가는 성장과정에 있는 유아들의 식이를 제한하지 않 았으며 신체활동으로 인한 에너지 소비 증가가 음식섭취의 증가를 유발하여 체지방량이 증가함에 따른 결과라고 사료된 다. 또한 이 시기에는 음식에 대한 자기억제 및 조절이 어려운 시기이기 때문에 음식섭취로 인한 영향이 많았을 것으로 사료 된다. 하지만 비만군에서 HDL-C의 변화는 없었지만 정상군 에서 HDL-C가 유의하게 증가한 것은 유아체육프로그램이 정 상군에게는 긍정적인 결과를 줄 수 있음을 시사하고 있다. 하 지만 대사증후군과 관련된 심혈관질환 및 제 2 형 당뇨병의 예 방과 처치에 있어 운동과 생활양식수정을 병행한 프로그램의 실시가 가장 이상적인 중재방법의 하나라고 할 수 있으며, 이 는 여러 연구결과에서 입증되었고 권장되고 있다 $[15,20,21]$. 따 라서 비만유아들에게 생활양식수정을 병행한 운동프로그램 이 어떠한 효과가 있는지 그 결과를 재검토해 볼 수 있는 후속 연구가 필요한 것으로 생각된다.

\section{체력의 변화}

비만유아들은 신체활동에 있어 보통체형의 유아들보다 적 극적이지 못하고 소극적이며, 비만의 원인이 유전요인 보다는 소극적인 신체활동과 과식 등 환경요인이 크게 작용하기 때문 에 비만예방을 위한 신체활동과 체력증진을 위한 신체교육프 로그램의 중요성이 강조되고 있다[5]. 본 연구에서 유아체육프 로그램에 따른 비만군과 정상군의 체력 변화는 비만군에서 근지구력, 순발력, 평형성, 협응성이 유의하게 $(p \times 0.05)$ 증가하 였고, 정상군에서 근지구력, 유연성, 평형성이 유의하게 $(p<0.05)$ 증가하였으며, 협응성 또한 유의하게 $(p<0.001)$ 증가 한 것으로 나타났다. 성인의 비신체활동과 낮은 수준의 체력 은 만성질환의 유병율과 사망률을 증가시키는 것과 관련이 있지만[12], 아동의 경우 비신체활동과 낮은 수준의 체력은 심 혈관위험인자의 발병률을 증가시키는 것과 관련이 있는 것으 로 보고 되고 있다[17]. 유아기에 신체활동을 통한 체력증진은 아동기 및 성인기에 발생될 수 있는 여러 가지 문제점을 사전 에 예방할 수 있는 긍정적인 효과를 얻을 수 있을 뿐 아니라 신체활동의 즐거움, 운동기술을 습득할 수 있는 중요한 시기 이다. 따라서 본 연구에서 시행한 유아체육프로그램이 체력을 향상시키는데 있어서 비만군과 정상체중군 모두 긍정적인 효 과를 가져오는 것으로 나타났다.

\section{성장관련인자의 변화}

뇌하수체 전엽에서 분비되는 성장호르몬은 골격, 근육 등을 포함하여 신체 전반에 대한 성장을 촉진하는 한편, 지방조직 에서 중성지방의 가수분해를 촉진하고 지방산을 혈중에 방출 하여 말초조직의 지방산 이용을 촉진하기 때문에 비만에서의 성장호르몬 감소는 체지방 분해에 부정적인 작용을 한다[19].
따라서 성장과정에 있는 유아들의 비만은 결국 발육발달에 부정적인 영향을 미칠 수 있다. 본 연구에서 유아체육프로그 램 실시에 따른 $\mathrm{GH}$ 의 변화는 비만군에서 유의한 차이가 없는 것으로 나타났다. 하지만 정상군은 유의하게 $(p<0.05)$ 증가한 것으로 나타났다. 성장호르몬 민감성을 높이기 위한 방법으로 운동을 포함한 생리학적 자극이 필요하며, 운동을 통한 성장 호르몬 증가는 체력 수준, 운동 강도 등에 영향을 받는다[23]. 또한 장시간 운동을 실시할 경우 성장호르몬의 분비가 증가되 어 IGF-I의 합성을 촉진하게 되며, 운동에 따른 근수축이 활발 하게 이루어져서 골격근의 성장 및 비대를 유발하는 것으로 보고하고 있다[9]. 이러한 선행연구의 결과를 고려해 볼 때 본 연구에서 시행된 유아체육프로그램은 비만군 보다는 정상군 에게 성장호르몬 분비를 촉진시키는데 더 효과적인 것으로 나타났으며, 비만군 유아들에게 좀 더 효과적인 유아체육프로 그램 개발을 위한 후속 연구가 필요한 것으로 생각된다. 운동 은 신체에서 성장호르몬을 분비시키기 위한 중요한 생리적 자극이며, 운동자극에 의한 신경전달물질은 성장호르몬 조절 에 관여하게 되며, 특히 성인보다 아동에게서 신체 운동 후 성장호르몬의 분비가 높다는 것이 보고되고 있다[2]. 또한 신 체 발육발달과 관련하여 성장호르몬을 합성, 분비시키는 생리 적 자극으로 규칙적인 운동을 실시할 경우 내분비계의 변화와 체력향상 및 건강증진을 위해 매우 효과적이다[11,16]. 본 연구 에서 IGF-I 또한 정상군에서 유의하게 $(p<0.05)$ 증가한 것으로 나타났으며, IGF-I은 성장을 촉진하는 활성 물질로 인슐린과 같은 대사적 효과를 발휘 할 뿐 아니라, 조직의 발육과 발달에 관여하며, 장기간의 지속적이고 계획적인 운동이 아동의 혈중 IGF-I과 IGF-I mRNA의 분비를 활성화시킨다고 보고되고 있 다[8]. 본 연구에서 실시한 12 주간의 운동이 성장을 촉진하는 활성 물질인 IGF-I 농도의 상승에도 긍정적인 영향을 미쳤으 며, 선행 연구에서도 규칙적인 장기간의 유산소성 운동이 성 장 호르몬의 분비는 물론 IGF-I의 분비를 자극함으로써 신체 의 성장과 발달에 영향을 미쳐 체력 증진과 건강증진에 매우 효과적이라는 사실을 입증하고 있다[9]. 따라서 정상체중유아 들의 경우 유아체육프로그램에 장기간 지속적으로 참여할 경 우 성장호르몬의 분비를 활성화시키고 성장을 촉진시키는 활 성 물질의 분비에도 긍정적인 영향을 미쳐 유아기의 체육프로 그램 참여가 발육발달에 긍정적인 영향을 미칠 수 있으며, 신 체발달을 증진시키는데 매우 효과적인 방안으로 사료된다.

이상의 연구결과를 종합해 볼 때 유아체육프로그램 실시가 체력 향상 측면에서 정상군과 비만군 모두에게 긍정적인 변화 를 가져오는 것을 확인 할 수 있었다. 하지만 본 연구의 유아체 육프로그램이 정상체중의 유아들에게는 GH와 IGF-I의 분비 를 자극함으로써 신체의 성장과 발달에 긍정적인 변화 가져올 것으로 기대할 수 있었으나 비만 유아들에게는 긍정적인 효과 를 얻지 못했다. 또한 비만군에서 혈중지질 인자에 긍정적인 효과가 나타나지 않았는데, 긍정적인 효과를 얻기 위해서 운 
동프로그램과 병행하여 생활양식수정 및 식이요법을 실시해 야 하는 것으로 해석할 수 있으며, 이를 재검토할 수 있는 후속 연구가 필요할 것으로 생각된다.

\section{References}

1. Bergstrom, E., O. Hemell, and L. A. Persson. 1997. Endurance running performance in relation to cardiovascular risk indicators in adolescents. Int. J. Sports Med 18, 300-307.

2. Cappa, M., C. Bizzarri, C. Martinez, O. Porzio, G. Giannine, A. Turchetta, and A. Calzolari. 2000. Neuroregulation of growth hormone duriong exercise in chidren. Int. J. Sport Med 21, 25-28.

3. Consitt, L. A., J. L. Copeland, and M. S. Tremblay. 2001. Hormone responses to resistance vs endurance exercise in premenopausal females, J. Appl. Physiol. 26, 574-587.

4. De vol, D. L., P. Rotwein, J. L. Sadow, J. Novakofski, and P. J. Bechtel. 1990. Activation of insulin-like growth factor gene expression during work-induced skeietal muscle groth. Am J. Physiol. 259, 9-95.

5. Dobbins, M., K. De Corby, P. Robeson, H. Husson, and D. Tirilis. 2009. School-based physical activity programs for promoting physical activity and fitness in children and adolescents aged 6-18. Cochrane Database Syst. Rev. 21, CD007651.

6. DuBose, K. D., J. C. Eisenmann, and J. E. Donnelly. 2007. Aerobic fitness attenuates the metabolic syndrome score in normal-weight, at risk for overweight and overweight children. Pediatrics 120, 1262-1268.

7. Durstine, J. L., P. W. Grandjean, C. A. Cox, and P. D. Thompson. 2002. Lipids, lipoproteins, and exercise. J. Cardiopulm Rehabil. 22, 385-398.

8. Eliakim, A., T. P. Scheett, R. Newcomb, S. Mohan, and D. M. Cooper. 2001. GH response to exercise: assessment of the pituitary refractory period, and relationship with circulation components of the GH-IGF-I axis in adolescent females. J. Pediatr. Endocrinol. Metab. 12, 47-55.

9. Fan, R. R. and J. L. Hodgson. 1994. Effect of resistive training in plasma lipid of lipoprotein levels in male adolescents. J. Pediatr. 111, 926-931.

10. Galbo, H. and P. Gollick. 1983. Hormonal changes during and after exercise. Med Sprots Sci. 17. 97-110.

11. Gibney, J., M. L. Healy, and P. H. Sonksen. 2007. The growth hormone/insulin-like growth factor-1 axis in exercise and sport. Endocr. Rev. 28, 603-624.

12. Hu, F. B., W. C. Willett, T. Li, M. J. Stampfer, G. A. Colditz, and J. E. Manson. 2004. Adiposity as compared with physical activity in predicting mortality among women. $N$. Engl. J. Med 351, 2694-2703.

13. Katzmarzyk, P. T., A. S. Leon, T. Rankinen, J. Gagnon, J. S. Skinner, and J. H. Wilmore. 2001. Changes in blood lipids consequent to aerobic exercise training related to changes in body fatness and aerobic fitness. Metabolism 50, 841-848.

14. Kim, H. J., J. W. Kim, and G. H. Park. 2007. The effects of aquatic exercise program on obese index, growth hormone, IGF-1 and vas in obese women with osteoarthritis of the knee. Korean J. Physical Edu. 48, 579-591.

15. Kwak, Y. S. and D. J. Kim. 2008. The Effects of the Complex Training Program on Cardiovascular Disease Risk Factors and Rate of Changes in the Elderly Women with Cardiovascular Disease. J. Life Sci. 18, 715-723.

16. Liu, H., D. M. Bravata, I. Olkin, A. Friedlander, V. Liu, B. Roberts, E. Bendavid, O. Saynina, S. R. Salpeter, A. M. Garber, and A. R. Hoffman. 2008. The Effects of Growth Hormone on Athletic Performance. Ann. Int. Med 148, 747-758.

17. McKenzie, T. L., J. F. Sallis, B. Kolody, and F. N. Faucette. 1997. Long-term effects of a physical education curriculum and staff development program: SPARK. Res. Q. Exerc. Sport 68, 280-291.

18. Munoz, M. T., G. Morande, C. J. A. Garcia, F. Hervas, J. Pozo, and J. Argente. 2002. The effects of estrogen administration on bone mineral density in adolescents with anorexia nervosa. Eur. J. Endocrinol. 146, 45-50.

19. Nam, S. Y., J. I. Son, K. W. Kim, U. I. Park, J. U. Kim, W. H. Park, S. B. Yun, K. R. Kim, K. S. Song, Y. D. Song, and S. K. Lim. 2000. Effect of GH treatment with diet restriction on GHBP level in obese subjects. Korean Society Study Obesity 9, 112-121.

20. Pan, Y. and C. A. Pratt. 2008. Metabolic syndrome and its association with diet and physical activity in US adolescents. J. Am Diet. Assoc. 108, 276-286.

21. Park, C. H. and T. G. Park. 2009. Effects of aerobic exercise plus lifestyle modification program on obese-induced metabolic syndrome in obese adolescent girls. J. Life Sci. 19, 198-205.

22. Park, T. S. 2002. Development of physical education program based on fundamental motor skill development in infant. Korea Society Early Childhood Physical Edu. 3, 79-100.

23. Petra, K., M. Madelon, W. Simon, H. A. Inge, J. Peter, and P. Hanno. 2003. Acipimox Enhances Spontaneous Growth Hormone Secretion in Obese? Am J. Physiol. 10, 1152-1160.

24. Resicow, K. and A. Morabia. 1990. The relation between body mass index and plasma total cholesterol in a multiracian sample of US school children. Am J. Epidemiol. 132, 1083.

25. Tomporowski, P. D., C. L. Davis, P. H. Miller, and J. A. Naglieri. 2008. Exercise and children's intelligence, cognition, and academic achievement. Educ. Psychol. Rev. 20, 111-131.

26. Tomporowski, P. D., K. Lambourne, and M. S. Okumura. 2011. Physical activity interventions and children's mental function: an introduction and overview. Prev. Med 52, S3-9. 
초록 : 유아체육프로그램이 정상체중유아와 비만유아의 체력과 혈중지질 및 성장관련인자에 미치는 영향 박형곤 ${ }^{1}$ 김군도 ${ }^{2} \cdot$ 박찬호 $^{1}$ *

( ${ }^{1}$ 부산대학교 체육교육과, ${ }^{2}$ 부경대학교 미생물학과)

본 연구는 비만유아 7명과 정상체중유아 7명을 대상으로 유아체육프로그램이 신체조성, 체력, 혈중지질 및 성 장관련인자의 변화를 분석하기 위해 실시되었다. 본 연구에서 실시한 유아체육프로그램이 체지방량을 감량시키 는데 효과적인 결과를 얻지 못하였지만 비만군과 정상체중군 모두 체력은 향상되는 것으로 나타났다. 그리고 정 상체중유아들의 경우 HDL-C와 제지방량의 증가는 본 연구에서 실시한 유아체육프로그램이 성인기의 비만과 성 인병 예방 측면에서 정상체중유아들에게 권장될 수 있는 것으로 사료된다. 또한 성장관련인자 IGF-I은 성장을 촉진하는 활성 물질로 성장호르몬 분비의 증가에 따라 IGF-I 농도 역시 상승한다. 본 연구에서도 정상체중군에서 긍정적인 효과가 나타나 유아체육프로그램이 성장기 유아의 성장호르몬의 분비를 활성화시키고 성장을 촉진시 키며 신체발달을 증진시키는데 도움을 줄 수 있을 것으로 생각한다. 